(昭和 32 年 8 月 9 日受理)

\title{
撚りの構造に関する研究
}

\section{第7報 ストレッチャーンの構造について}

群馬大学工学部中里恵一・松田和夫・淵野桂六

\section{STUDIES OF THE STRUCTURE OF TWISTED YARN (VII) ON THE STRUCTURE OF A STRETCHED YARN}

By Keiich Nakazato, Kazuo Matsuda and Keiroku Fuchino

(Faculty of Engineering, Gunma University, Kiryu, Japan)

The number of twist, and the untwisting moment of a spring with different helical angle, made by nylon fish line, are measured by the usual moment tester, for the study of the mechanism of the stretched yarn.

The results obtained by previous investigation may be explained by the following considerations :-

(1) The fact that early in its untwisting operation reverse twists that appear, may be explained by the energy that the reverse twists have lower energy tha untwisted normal twist.

(2) The results that the sum of normal and reverse twists are always kept constant until all the normal twists change to reverse twists are derived from the constant helical angle throughout in the constant length untwisting.

(Received 9. 8. 1957)

今日のいわゆる Helanca Yarn, Woolie Nylon など はいずれもナイロッの引揃系に撚りをが，熱セット後， オーパー解撚なる操作によつて作られるるのでする。こ の現象は熱可塑性を有寸る合成絨維特有の性質として知 られ，長緎維の擬正化の有力な手段である。すれわれは 最も簡単なモデルタースとしてスプリングを用い，一端 を固定して解撚を行つた。解撚が進もにつれて然りの逆

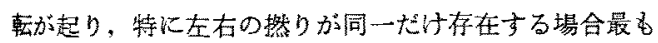
伸綰性が大きく，その㭙をーメントが一定なることを見 出し, この点が Helanca あるいは Woolie nylon の超 過解然の必要な委件ではあるまいかということを先に報 告した。本報告は能報告1)の不檞の点を補い,ナイロン 引揃系の施撚一七ット一解撚の操作について考寗した結 果垛告する。

\section{1. 解然に伴う逆撚りの発生について}

前報て一端を固定したスプリングの解然に伴 5逆称り の発生について報告したが、不满の点があるのでここで 再び考察する。

スプリングの解撚の進むにつれてある点から一部の撚 りの逆鞋が起り，後は一回解撚する毎に $1 / 2$ の撚りが失 かれ新しく $1 / 2$ 逆撚りが発生し，需解然に括いては正 然り之逆筫りの数は等しくなる。かかる現象はスブリン グを延伸して見挂上直繶にして需解然を行い，その後一
端を近ずけて弛めても同じように起る。このことは次の 如く濐党れば当然である。すなわら上述の操作に尔いて は奏際上然りは0で放るから，安定然として如何なる 撚りが発生してもその総和は0でなければならない。し

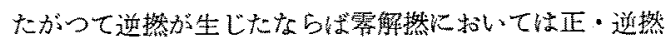
りが同数存在し，然数の代数和注0になつていなけ机ば ならない。なにゆえ逆撚が発生するかという点和上び第 1 表に見られる如く绐めの撚数のちょ 5 ど半分が正逆化

\begin{tabular}{|c|c|c|c|c|}
\hline 解撚数 & $\begin{array}{l}\text { スブリン } \\
\not ゙ の \text { 撚り }\end{array}$ & 同逆撚り & false points & 試 \\
\hline 0 & 50 & 0 & 0 & \\
\hline 13 & 42 & 5 & 1 & \\
\hline 50 & 24 & 24 & 1 & \\
\hline 0 & 20 & 0 & 0 & \\
\hline 6 & 16.5 & 2.5 & 1 & \\
\hline 20 & 9.5 & 9.5 & 1 & \\
\hline 0 & 20 & 0 & 0 & \\
\hline 5 & 16.5 & 1 & 1 & $40 \mathrm{~cm}$ \\
\hline 20 & 9.5 & 9.5 & 1 & \\
\hline 0 & 20 & 0 & 0 & \\
\hline 6 & 15.5 & 1.5 & 1 & $50 \mathrm{~cm}$ \\
\hline 20 & 8.5 & 8.5 & 1 & \\
\hline
\end{tabular}


生じない理由は後に考察する。

\section{2. 解撚に伴なうモーメントの変化}

上述の如き然りの逆枟の起る理由の解明のためにまず モーメント一撚助線について考察して見る。测定に用い た装睥は第 1 図に示す如き普通にモーメントの測定に用 いられるるのである。試料は約 $2500 \mathrm{~d}$ のナイロンテグ スをガラス棒に巻き， $190^{\circ} \mathrm{C}$ 乾熱せットしたものを用い た。初めスプリングはセットした状態 より少し延して澌定を始める（全然延 ばさないものは解然に伴なつて形がく

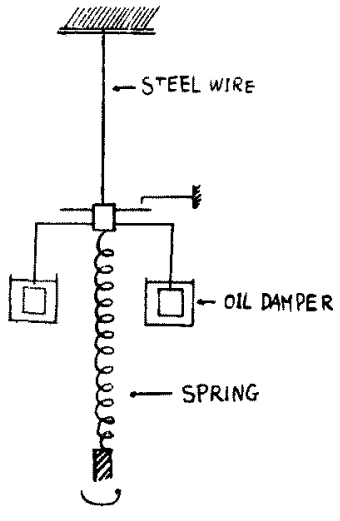

Fig. 1 Measuring Appartus

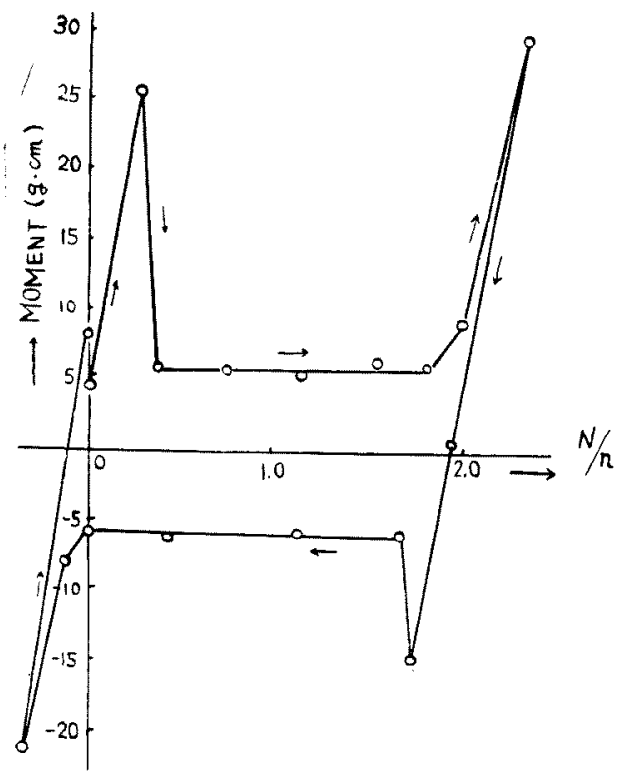

Fig. 2 Moment-untwist diagram. set angle : $\varphi_{0}=90^{\circ}$, strting angle ; $\varphi=45^{\circ}$
ずれて湘定が不能になるつ。第2四にえられた結果を示 す。解撚するにしたがつて，モーメントは住ば直線的に 增加するが、ある点に莘すると逆転が生じ，その瞬間にモ 一メントは減少する。それ以後は解然が進んでるモーメ ントは一定で逆然りが增加し，全部逆然りになれば再び 上䄯し始める。（前報に打いては装置の関係から，この ように逆転の咸にモーメントの減少が起ることは見出し えなかつたのでここに訂正する。

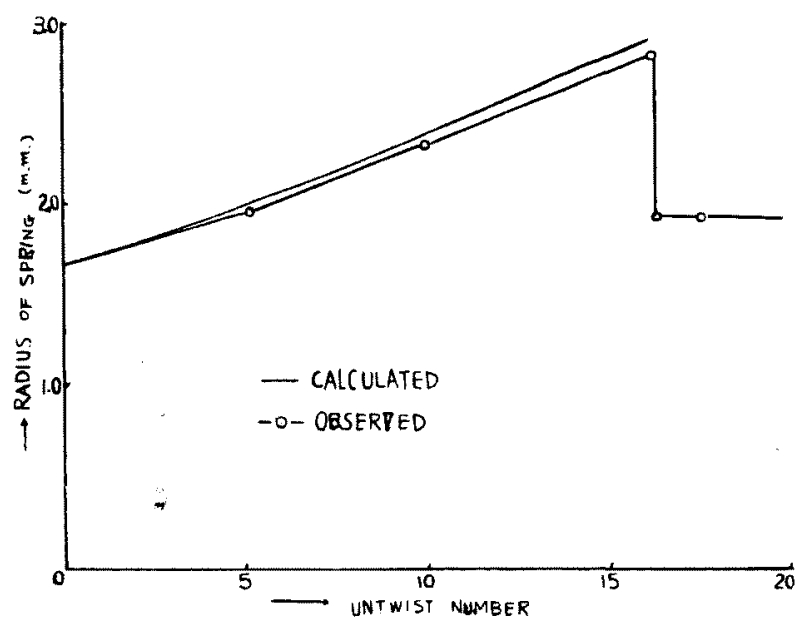

Fig. 3 Change of radius of spring in its untwisting. spring ; $37 \mathrm{~T} / 40 \mathrm{~cm}$

一定長で解撚する場合は常に撚り角は一定である筈で あり，次のよ5に解然は進行する。

$$
\begin{gathered}
\sin \varphi=\frac{2 \pi n R_{1}}{L}=\frac{2 \pi(n-N) R}{L}=\text { const. } \\
\therefore n R_{1}=(n-N) R
\end{gathered}
$$

ここに $N$ は解撚数, $n$ は始めのスプリングの撚数, $R_{1}$ は解撚を始める時のスプリングの半径， $R$ は $N$ だけ解 撚した場合の半径， $L$ は素線の長さである。このことは 実験結果とよく一致している。（第 3 図）

一般にスプソングの一端に作用するモーメントは次の ごとく与えられる2〉8)。

$$
\begin{aligned}
M=G I_{p} \cos \varphi\left(\frac{\sin \varphi \cdot \cos \varphi}{R}-\frac{\sin \varphi_{0} \cos \varphi_{0}}{R_{0}}\right) \\
+E I \sin \varphi\left(\frac{\sin ^{2} \varphi}{R}-\frac{\sin ^{2} \varphi_{0}}{R_{0}}\right)
\end{aligned}
$$

ここに $G, E, I_{p}, I$ はナイロンテグスの常数, $R_{0}, \varphi_{0}$ は セット特の半径と然角。この式に解撚の条件 (1)を入れ て整理すれば次のような形になる

$$
M=A+B N \quad A, B \text { は常数 }
$$

もし理想的に解撚が行われればこの式から，はなれるこ とはないわけであつて，逆転の理由は别に求めなけれ 
狆ならないであろう。さらに考察を進めるために次に， このことをニネルギー的に眺めてみる。

\section{3. 解撚の際のエネルギ变化}

一般にスプリングの持つモーメントは曲げモーメント

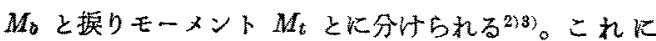
対応して查エネルギーはそれぞれ次式で表わされる。

$$
\begin{gathered}
U_{b}=\int_{0}^{l} \frac{M_{b}^{2}}{2 E I} d x=\frac{E I l}{2}-\left(\frac{\sin ^{2} \varphi}{R}-\frac{\sin ^{2} \varphi_{0}}{R_{0}}\right)^{2} \\
U_{t}=\int_{0}^{l} \frac{M_{t}^{2}}{2 G I_{p}} d x=\frac{l G I_{p}}{2}\left(\frac{\sin \varphi \cdot \cos \varphi}{R}\right. \\
\left.-\frac{\sin \varphi_{0} \cdot \cos \varphi_{0}}{R_{0}}\right)^{2}
\end{gathered}
$$

一定長の解然の場合は（1）を考慮して

$$
\begin{gathered}
U_{b}=C\left\{\left(1-\frac{N}{n}\right) \sin \varphi-\sin \varphi_{0}\right\}^{2} \\
U_{t}=\alpha C\left\{\left(1-\frac{N}{n}\right) \cos \varphi-\cos \varphi_{0}\right\}^{2} \\
C: \text { 常数 } \quad \alpha=E I / G I_{p}
\end{gathered}
$$

われわれの問題はなにゆえに解撚の途中で逆鞋が起る かとい5点である。今仮りに $n$ 個の然りが $N$ だ解然

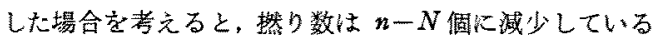
等であるから，一定の長さに $n-N$ 個の然りが如何に分 布されるかといら問題に帰着する。この場合われわれは セットされた最初のスプリングの撚角が解撚雤作に求い，

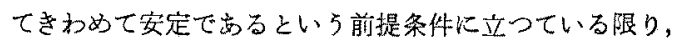
そのならへかたは次の3種が可能である。

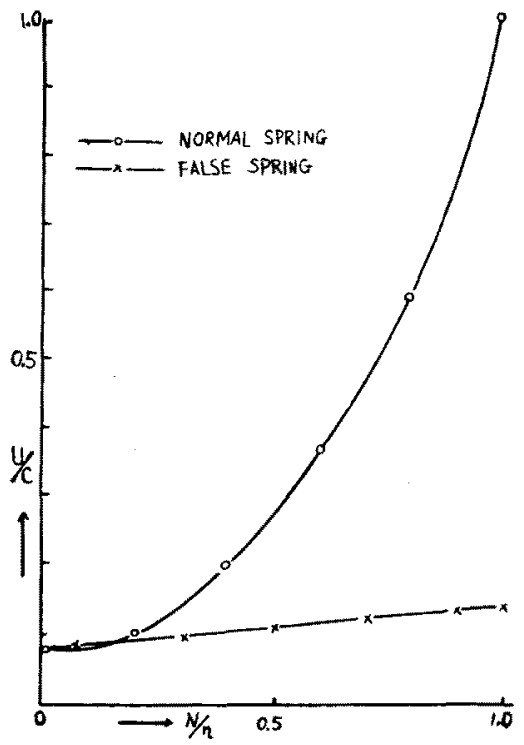

Fig. 4(a) Change of strain energy of spring by untwisting. : $\mathscr{P}_{0}=90^{\circ}, \quad \rho=60^{\circ}$
（1）半径が增加されてnーN 俔の然りを持つ場合

（2） $n$-Nの撚りを持つために $n-\frac{1}{2} N-\frac{1}{2}$ 個の正 撚りと $\frac{1}{2} N-\frac{1}{2}$ 個の逆撚りと一つの变换点を持つ 埸合

(3) (1) と(2) の其存

解热の際にいずれの安定の場合る取るかは土ネルギー の少ない方をとるであるら。奏際の解撚の際に起るのは

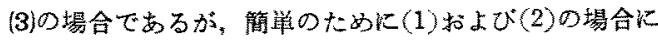
ついてェネルギーを䚺算した結果は第 4 図の如くである。 ただし (2) の場合に変换点は和視し，逆撚りは理想化 L て諳算を行つた。図に示寸如く解撚の進行に伴つて(2)の

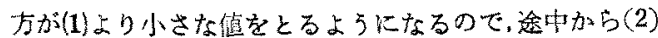

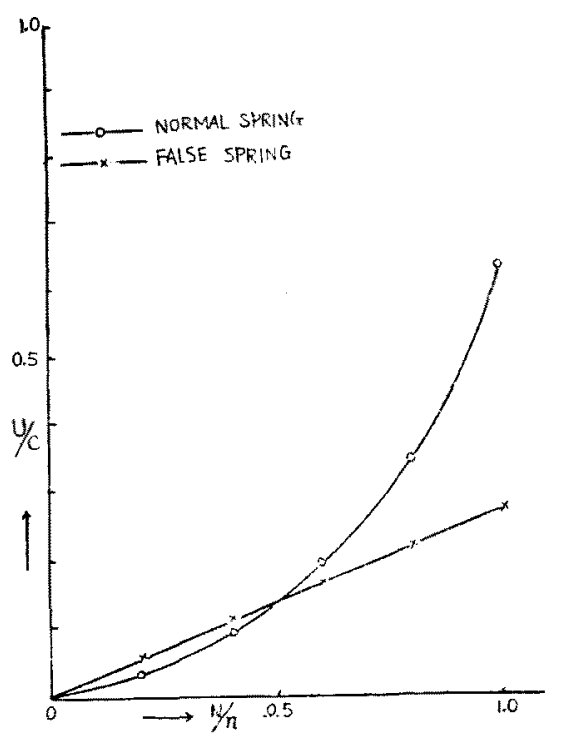

Fig. 4 (b) Change of strain energy of spring by untwisting. $\varphi_{0}=\varphi=45^{\circ}$
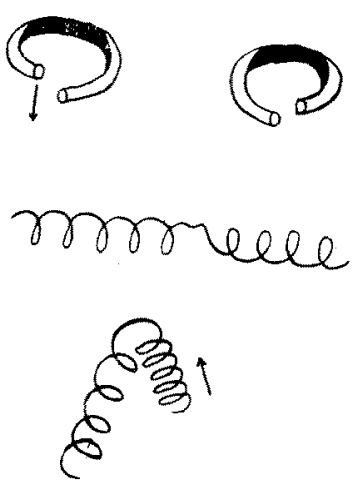

Fig. 5 Model of normal and reverse twist. 
又は(3)の状態に移ることが考えられる。ただし第 1 表に 見る如く正逆撚りが同数でも，その和が $n$ 上り少い場合 があるのは（3）の場合であって，発生した正逆撚りの 半径が完全に始奶值にるどらないためである。このこ とは第 2 図で逆転が起つてもモーメントが0にならない ところにも表秃ている。

逆撚りといらのは第 5 図の如く正撚りを引張つた形に なつているので, 収縮力が生じ両端を自由にすれ代密着 した状態になる傾向がある。したがって全部逆転したス プリングは密になり，きわめて収縮力に富んだものがで きる。

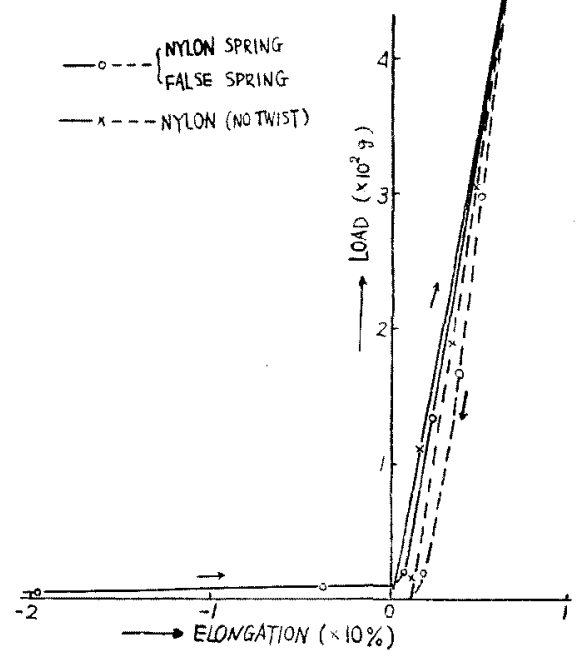

Fig. 6 Load-elongation curve of spring and fiber.

\section{4. 正逆撚りの共存するスプリング の力学的性䨘}

\section{(1) 強伸度曲線}

第6四にフミミンテグスから作つたスプリングとテグ ス自身の荷重伸長曲線を画いた。スプリングの捴縮はわ ずかな荷重で伸び，伸びきつてからは汪とんど普通の荷 重伸長曲線に一致している。このことは中央に false point を持つスプリングでも同じである。

(2) 伸長に伴なうモーメントの変化

第 7 図にスプリング㕲よび同一のスプリングである が,中央に false point を有するすのの延伸に伴らモー メントの変化を图示した。普通のスプリングが一旦上年 して後减少するのは，(2) 式に伸長の条件を入れた場合 と一致した傾向を示している。正逆同数然りのものは伸 長に伴つて false point が回転し全体としての回転は生

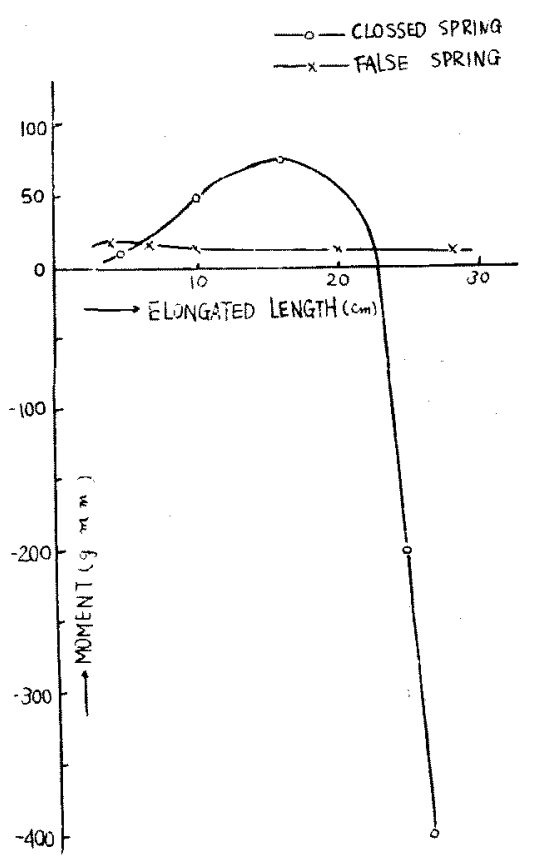

Fig. 7 Moment-elongation diagrams of spring じない。

(3) False point $の$ 安定度

次に false point にこく小さい荷重の羽毛をつけて延 伸し，羽毛の回転角学測つた(第 8 図)。図に示すごとく延

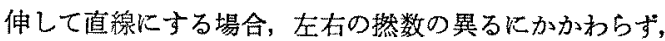
延伸拉よび回復においてきわめて安定であることがわか

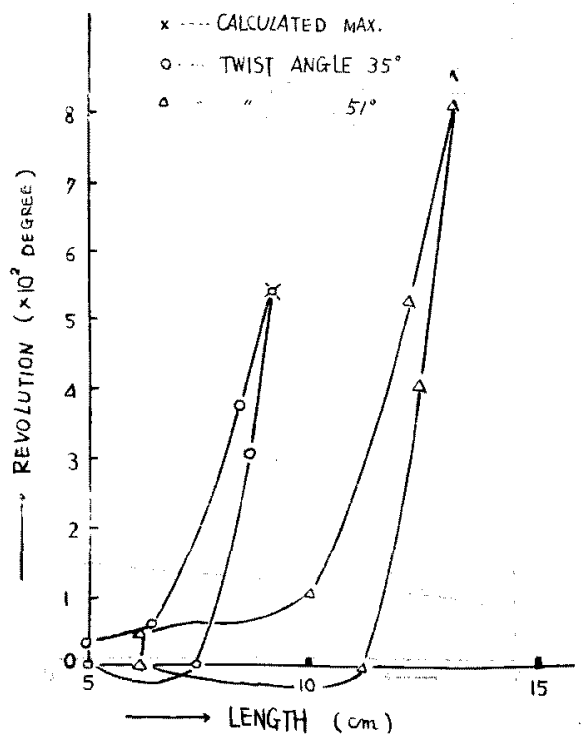

Fig. 8 Revolution of false point 
た。图において×点は同じ数の正逆撚が消失して多いっ の然りが全体に一様伝播するとしたときの計算值であ る。

\section{5. 撚角の小さいスプリングの解撚}

第 2 四に示したモーメント一撚曲楾は比較的大きな撚 角を持つたるのの場合であつて，撚角の小さなスプリン グ(前のむのをある程度引伸してセットしたもの)の場合 は第 9 図に示す如く少し違つた挙動をする。解撚に従つ

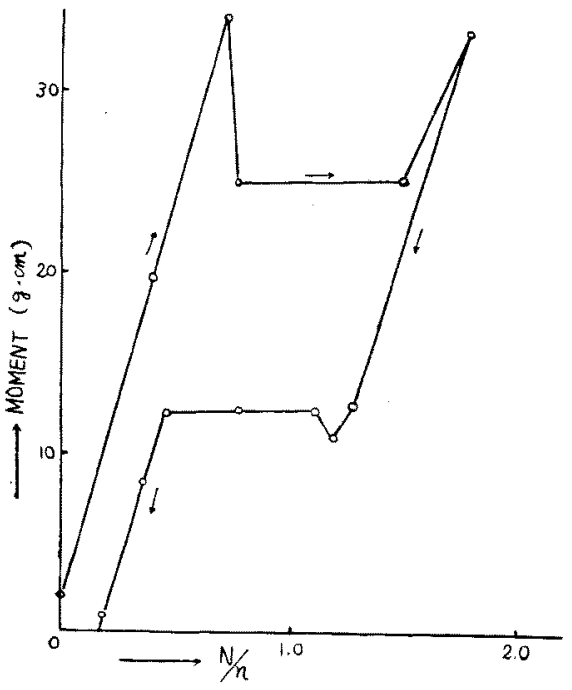

Fig. 9 Moment-untwisting diagram $\varphi_{0}=\phi=30^{\circ}$
て逆䩓が生じモーメントが落ちることは同じであるが， その時相当大きなモーメントが残る(従つて全然数は減 少していて $N$ が $2 n$ にならないで全部逆転する)。全 逆䎐の状態から元に爰す場合，第2図とは違つてモーメ ントが0にならないうちに正転が始まる。このスプリン グを正逆撚共存の所で両端自由にすれば強い残留モー メントのために収縮しながらねじれて復犨な形となる。

\section{6. ストレツチャーンの構造 について}

ナイロンの引搠系を撚つてセットした場合，これを種 ↔の撚角を持つスプリングの集りと考学ることができ る。これを零解撚近くに解撚すればそのままでは false point ができてもモースントは残る。これはダブリング の必要な点であるが，前節に述べた如く外側の然り角の 大きな䋐維は仮撚状態で安定するが，内側の然角の少い 㵶維は安定せず，周四のゆるす限り放じれながら取維し 上うとし強い収縮力と鍇綜した形を取ることになる。

釉りに試料を恵与された東洋レーヨンならびに実験の 一部を担当された本学仲道弘，須永安夫両君に感謝の意 を表します。

文献

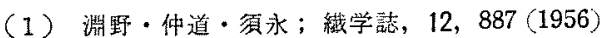

(2) Love; The Mathematical Theory of Elas. ticity. (1927)

(3) H.W. Holdaway ; J. Text. Inst. 47, T 586 (1956)

本学会誌のハッックナンバー買取りについて

会員各位の中で不要の下記バックナンバーの手持らがめりましたら本学会に拈いて買取りますから扰送 り下さい。

Vol. 1-1, 2, 3, 6, 8,9月 (昭和 19 年)

Vol. 2-3, 10, 12 月 (昭和 21 年)

Vol, 3-2, 10 月 (昭和 22 年)

Vol. 4-4月 (昭和 23 年)

Vol. 7-5，6，7，8，9，10，11-12 合併号（昭和 26 年）

Vol，8-1，2，3，4月 (昭和 27 年) 